\title{
Seroprevalence of Foot and Mouth Disease virus antibodies in trade cattle (Bos indicus) in Kwara state of Nigeria
}

\author{
O. H. Olabode ${ }^{1,2}$, H. M. Kazeem ${ }^{2}$, M. A. Raji ${ }^{2}$ and N. D. Ibrahim ${ }^{2}$
}

1. Department of Veterinary Microbiology, Faculty of Veterinary Medicine, University of Abuja, Abuja, Nigeria

2. Department of Veterinary Microbiology, Faculty of Veterinary Medicine, Ahmadu Bello University, Zaria, Nigeria Corresponding author: O.H Olabode Email: olabodeok@yahoo.com, Telephone: +2348023806741

Received: 23-05-2013, Revised: 24-07-2013, Accepted: 25-07-2013, Published online: 17-09-2013

doi: $10.14202 /$ vetworld.2013.828-832

How to cite this article: Olabode OH, Kazeem HM, Raji MA and Ibrahim ND (2013) Seroprevalence of Foot and Mouth Disease virus antibodies in trade cattle (Bos indicus) in Kwara state of Nigeria, Veterinary World 6(10): 828-832.

\begin{abstract}
Aim: A serological survey for the detection of Foot and Mouth Disease virus antibodies in trade cattle was conducted to determine the seroprevalence of Foot and Mouth Disease (FMD) in the Kwara state of Nigeria.

Materials and Methods: A cross-sectional study based on convenient sampling for bovine blood was carried out in 5 cattle markets (Offa, Bode Sadu, Ilesha baruba, Ilorin, Ajasse) across five local government areas in Kwara State amongst cattle with unknown history of FMD vaccination over a period of August-September-October, 2011. The sera obtained were screened using NS-Blocking ELISA kit (PRIOCHECK ${ }^{\mathrm{R}}$ ).

Results: Out of the 450 cattle (268 cows and 182 bulls) screened for FMD antibodies, sero-positivity was highest amongst cows $62.13 \%$. Percentage distribution of sero-positive reactors by location showed Ilesha baruba, Ilorin and Offa had $27.14 \%$, $23.80 \%$ and $13.33 \%$ respectively, while seropositivity amongst bulls was $37.86 \%$, highest occurrence in Offa $30.46 \%$ and least in Ilesha baruba $14.84 \%$. FMD carriers according to breeds showed $77.21 \%$ white Fulani (Bunaji) was positive over the other breeds. The sex, location and breed was significant by chi square $\mathrm{p}<0.05$. FMD seropositivity according to age indicated young cattle within 6 months-2years group had the highest occurrence $75.14 \%$ over the adult group $24.85 \%$.
\end{abstract}

Conclusion: The occurrence thus confirms FMD endemicity and susceptibility of all sex, ages, and various breed of unvaccinated trade cattle especially amongst white Fulani, young cows within the local markets and those from neighboring West African countries. Thus, circulating FMDV strains responsible for this seropositivity should be established in order to design appropriate control strategy to limit FMD effect.

Key words: Foot and Mouth disease virus antibodies, Kwara state, seroprevalence, trade cattle

\section{I ntroduction}

Foot and mouth disease (FMD), is a highly contagious viral disease of both domestic and wild cloven hoofed animals characterized by high morbidity and decreased livestock productivity, with affected countries being excluded from international animal trade [1]. FMD virus (FMDV) which consists of a single-stranded, positive-sense RNA genome, belonging to the family Picornaviridae that encodes a large polyprotein, which is then cleaved into the structural proteins and nonstructural proteins [2]. The seven distinct serotypes include Type A, O, C (European types), South African types $\left(\mathrm{SAT}_{1}, \mathrm{SAT}_{2}\right.$, $\mathrm{SAT}_{3}$ ) and Asiatic Type. Cumulative incidence of FMD serotypes showed that six of the seven serotypes $(\mathrm{O}, \mathrm{A}$, C, SAT-1, SAT-2, SAT-3) have occurred in Africa [3]. In Nigeria, previous reports confirm endemicity of FMD with serious economic losses due to serotypes A, and SAT 2 [4; 5], serotypes O, SAT1 and SAT2 [6]. SAT1 and SAT 2 serotypes antibodies were also demonstrated [7]. Reviews of FMD reported serotypes

Copyright: The authors. This article is an open access article licensed under the terms of the Creative Commons Attribution License (http://creativecommons.org/licenses/by/2.0) which permits unrestricted use, distribution and reproduction in any medium, provided the work is properly cited.
A, O, SAT 1 and SAT 2 have been responsible for disease outbreaks in Northern Nigeria as these serotypes have been in circulation in the last 54 years (1955-2009) [8;9]. The inaccurate reported endemicity of the disease [4] is associated to none reporting of disease outbreaks [5] due to inefficient disease reporting system in the country [10] and this has made planning for prevention and control of the disease very difficult [7]. Despite the endemicity of Foot and mouth disease, there is paucity of reported information as regards the dynamics and status of FMD in Kwara state where a high concentration of cattle herds is found. This was associated with insufficient control efforts which had made the disease endemic with mild course and mortality [11]. Serological demonstration of specific antibodies to non-structural proteins in nonvaccinated animals, where a vesicular condition is present, is sufficient for a positive diagnosis. This is particularly useful in mild cases or in cases where epithelial tissue cannot be collected [12]. The detection of antibodies to the NSP 3ABC of FMDV has been shown to be sensitive and specific method to differentiate between infection and vaccination [1317]. NSPs, unlike structural proteins, are highly conserved and therefore, are not serotype specific and as a consequence, the detection of these antibodies is 
not serotype restricted [18]. Enzyme-linked immunosorbent assay (ELISA) test is a more specific, sensitive, and fast and is independent of cell cultures and usually not affected by anti-complement factors present in the cattle serum. The ELISA can be performed with inactivated antigens, thus requiring less restrictive biocontainment facilities [19]. Hence serologic quantification of FMD antibody level to 3-ABC nonstructural protein can be used to establish the disease burden [14]. This premised the use of PRIOCHECK FMD-3ABC NS protein ELISA to establish the prevalence of FMD in Kwara State which hosts the Ilesha baruba cattle international market in Baruten LGA that shares an international border with Benin Republic.

\section{Materials and Methods}

Ethical approval: The research procedure was approved by the staff and postgraduates seminar committee of the Faculty of Veterinary Medicine, Ahmadu Bello University Zaria, Kaduna State of Nigeria. The samples were collected, stored and analyzed using ELISA kit as approved by the committee in accordance with the manufacturer's (PRIOCHECKR) recommendation.

Study area: Kwara State is also referred to as the 'gateway' State because of its location between the Northern and Southern parts of Nigeria. This State is a first order administrative division located on the longitude $\mathrm{N} 8^{\circ} 30^{\prime} 00^{\prime \prime}$ and latitude $\mathrm{E} 5^{\circ} 0^{\prime} 00^{\prime \prime} 8.5$ / 5 (Geo Name Id : 2332785) [20] with 16 Local Government Areas namely: Asa, Baruten, Edu, Ekiti, Ifelodun, Ilorin East, Ilorin West, Irepodun, Isin, Kaiama, Moro, Offa, Oke-Ero, Oyun, Ilorin south and Pategi. This state shares common boundaries with Niger and Kebbi States to the North, Oyo, Ondo and Edo States to the South, Benue, Plateau and Federal Capital Territory to the East [21]. It maintains an international boundary with the Republic of Benin to the West.

Study design: A cross-sectional study was designed using convenient sampling based on availability of cattle and the willingness of the cattle owners at various location covered by this study. The sampling was conducted fortnightly over a period of three months (August, September, and October, 2011). Five cattle markets in different local government areas was considered for this study based on their location and proximity to other States and international border (Benin republic, Niger, Oyo, Osun and Ekiti States). The markets include: Offa, Bode Sadu, Ilesha baruba, Ilorin and Ajasse in Offa, Moro, Baruten, Ilorin East, and Irepodun LGAs respectively for the collection of blood from trade cattle for separation into sera. Sex and breed was being noted as blood samples were collected for risk factor analysis. Ageing of the cattle was conducted as traditionally classified in Hausa/ Fulani languages during participatory epidemiology in accordance with local existing veterinary knowledge of the cattle marketers as earlier conducted [22]. The ages were designated in Hausa as Marki (male)/ Marka (female)/Wege (Fulani) as age from 6 months-2years. Bijimi (male)/Karsana (female) in Hausa while Nghari (Fulani) as from 3-5years above. Age was grouped into two categories: 6 months -2 years and 3 years and above.

Sample collection: Five milliliters of blood was collected from each well restraint animal through the jugular vein by using $10 \mathrm{ml}$ syringe and $18 \mathrm{G}$ needle into $5 \mathrm{ml}$ sample vials and kept at room temperature at an angle of $45^{\circ} \mathrm{C}$ for $6-8 \mathrm{hrs}$ to allow for clotting of blood and sera separation. The sera were aspirated into new set of $5 \mathrm{ml}$ plastic tubes, labeled, stored on ice pack and transported to the laboratory, National Veterinary Research Institute, Vom where it was kept at $-20^{\circ} \mathrm{C}$ until used.

Serological assay using FMDV-NS ELISA: FMDV NS for in vitro detection of antibodies against bovine FMDV in serum samples as described [16] was conducted using PrioCHECK ${ }^{\mathrm{R}}$ FMDV-NS blocking ELISA. The preparation of working solutions was conducted in advance, this include dilution buffer working solution, Additives, ELISA buffer, Conjugate dilution and Washing solution as recommended by the manufactures [Prionics Lelystad B.V.: The Netherlands].

On the second day, the test plates were coated with $3 \mathrm{ABC}$ specific monocolonal antibody (mAb), using $80 \mu 1$ ELISA buffer to wells of the plates. Twenty microliter $(20 \mu \mathrm{l})$ negative control was dispensed in wells A1 and B1, and 20ul of weak positive control was dispensed in wells C1 and D1 while $20 \mu$ l of positive control was dispensed in wells E1 and F1. The test was performed by dispensing the $20 \mu \mathrm{l}$ of test samples to the remaining wells of a Test plates, sealed using enclosed plate sealer and shaked gently prior to overnight incubation at $22+3^{\circ} \mathrm{C}$. After incubation the plates were washed six times with 200-300 $\mu$ l of washing solution and 100ul conjugate was added to all wells. The test plates were sealed using enclosed sealers and incubated for 60 minutes at $22+3^{\circ} \mathrm{C}$. FMDV NS specific antibodies, directed against the non-structural proteins that may be present in the test samples bond to the 3ABCprotein and hence blocked the binding of the mAb-HRPO. After incubation, the plates were washed six times with 200-300 $\mu 1$ washing solution (plates were tapped firmly after the last washing) and $100 \mu \mathrm{l}$ chromogen (TMB) substrate was dispensed to all the wells. After incubation at room temperature $\left(22+3^{\circ} \mathrm{C}\right)$ for 20 minutes the color development was stopped, by adding $100 \mu$ l of stop solution and mixed well prior measuring. The color development was measured optically at a wavelength of $450 \mathrm{~nm}$ to show the presence of antibodies directed against FMDV within 15 minutes after addition of stop solution. The $\mathrm{OD}_{450}$ value of all samples including the controls were calculated and expressed as percentage Inhibition (PI) relative to the $\mathrm{OD}_{450}$ max by first calculating the mean $\mathrm{OD}_{450}$ value of wells A1 and B1 
Table-1. Seroprevalence of FMD in cattle by sex in Kwara state

\begin{tabular}{lcccccccc}
\hline Location & $\begin{array}{c}\text { Female } \\
\text { sampled }\end{array}$ & $\begin{array}{c}\text { Male } \\
\text { sampled }\end{array}$ & $\begin{array}{c}\text { Positive } \\
\text { female }\end{array}$ & $\begin{array}{c}\text { Positive } \\
\text { male }\end{array}$ & $\begin{array}{c}\text { Negative } \\
\text { female }\end{array}$ & $\begin{array}{c}\text { Negative } \\
\text { male }\end{array}$ & $\begin{array}{c}\text { Total } \\
\text { positive }\end{array}$ & $\begin{array}{c}\text { Total } \\
\text { negative }\end{array}$ \\
\hline Offa & 36 & 54 & 28 & 39 & 8 & 15 & 67 & 23 \\
Bode Sadu & 60 & 30 & 41 & 24 & 19 & 6 & 65 & 25 \\
llesha & 71 & 19 & 57 & 19 & 14 & - & 76 & 14 \\
llorin & 63 & 27 & 50 & 20 & 12 & 8 & 70 & 20 \\
Ajasse & 38 & 52 & 33 & 27 & 5 & 25 & 60 & 30 \\
Total & 268 & 182 & 210 & 128 & 58 & 54 & 338 & 112 \\
\hline
\end{tabular}

Table-2. Seroprevalence of FMD in cattle by breed in Kwara state

\begin{tabular}{lccc}
\hline Type & Positive & Negative & Total \\
\hline White Fulani (Bunaji) & 261 & 45 & 306 \\
Sokoto guduali (Bokoloji) & 37 & 42 & 79 \\
Red Bororo (Rahaji) & 40 & 25 & 65 \\
Total & $338(75.11 \%)^{*}$ & 112 & 450 \\
\hline
\end{tabular}

* Prevalence of FMD carriers in cattle

(Negative Control $=\mathrm{OD}_{450} \max$ ). Then using the formula below;

$\mathrm{PI}=100-\left[\mathrm{OD}_{450}\right.$ test sample/OD $\left.{ }_{450} \max \right] \times 100$

A PI of $<50 \%$ was considered negative and it was interpreted that the animal tested had not been exposed to FMD for 40 days. A PI of $\geq 50 \%$ was considered positive and recent exposure $\langle 40\rangle$ days to FMD. More specifically, a PI value of $\geq 50 \%$ but $<70 \%$ was considered a weak positive result and a PI value of $\geq$ $70 \%$ was considered a strong positive result [16].

Statistical analysis: The positive reactors as well as the associated risk factors were expressed as simple descriptive statistics such as percentage/frequency and chats. The data was further subjected to chi square analysis using SPSS 19 software.

\section{Results}

The overall FMD seroprevalence recorded in this study was $75.11 \%(338 / 450)$ as shown in Table-1. The distribution of sero-positive reactors by location in different Local Government Areas in the state indicated that Ilesha baruba LGA recorded the highest occurrence of $22.48 \%(76 / 338)$. This was closely followed by Ilorin East LGA 20.71\% (70/338). Others include $19.82 \%(67 / 338), 19.23 \%(65 / 338)$ and $17.75 \%(60 / 338)$ in Offa, Bode Sadu and Irepodun LGAs respectively. Chi square analysis showed no statistical significance $(\mathrm{P}>0.05)$ of FMD in association with LGAs in the state especially in Offa, Bode Sadu, and Ajasse while Ilesha and Ilorin showed association with the occurrence of FMD. Out of 450 cattle screened, 268 were female (cows) and 182 was males (bulls). The highest number of females sampled was in Ilesha (71) and Ilorin (63) respectively, while the highest number of males sampled was in Offa (54) and Ajasse (52) respectively. The serpositivity was highest amongst female (cows) 62.13\% (210/338) with highest occurrence in Ilesha $27.14 \%$ (57/210), Ilorin $23.80 \%$ (50/210), and least $13.33 \%$ (28/210) in Offa. However, the seropositivity amongst male (bulls) was $37.86 \%$ $(128 / 338)$ with the highest occurrence in bulls in Offa $30.46 \%(39 / 128)$ and $21.09 \%(27 / 128)$ respectively
Table-3. Seroprevalence of FMD in cattle by age in Kwara state

\begin{tabular}{lccc}
\hline Age & Positive & Negative & Total \\
\hline Young (6 mths-2 years) & 254 & 44 & 298 \\
Adult (3-5 years) & 84 & 68 & 152 \\
Total & $338(75.11 \%)^{*}$ & 112 & 450 \\
\hline
\end{tabular}

* Prevalence of FMD carriers in cattle

and least in Ilesha 14.84\% (19/128). The cattle sex with location also showed statistical significance $(\mathrm{P}<0.05)$ with sampling locations (LGAs) $\left(\chi^{2}=45.4, \mathrm{df}=4\right)$ by chi square analysis.

The distribution of sero-positive FMD carriers according to breeds in this study (Table-2) showed that out of the 306 white Fulani (Bunaji) sampled $77.21 \%$ (261/338) was positive which indicated the highest occurrence over the other breeds of cattle. Red bororo (Rahaji) and Sokoto Gudali (Bokoloji) had 11.83\% (40/338) and 10.94\% (37/338) respectively. However, the seroprevalence of FMD in association with breed showed statistical significance $(\mathrm{P}<0.05)$ with white fulani $\left(\chi^{2}=57.2, \mathrm{df}=2\right)$ by chi square analysis.

Table-3 shows the distribution of FMD seropositivity according to age classification based on existing traditional knowledge of the marketers. The young cattle within 6 months - 2years group had highest occurrence $75.14 \%$ (254/338), while the occurrence was least in the adult group $24.85 \%$ (84/338). The seroprevalence of FMD in association with age showed statistical significance $(\mathrm{P}<0.05)$ with the young group of cattle ( 6 months- $2 \mathrm{yrs})\left(\chi^{2}=48.4\right.$, $\mathrm{df}=1$ ).

Table-4 shows Percentage Inhibition (PI) of sera samples from FMD trade cattle carriers at Optical density (OD) of 450nm as 112 negative sera (PI\% $<50 \%$ ), 69 sera as weak positive (PI\% $50-70 \%$ ) and 269 strong positive sera (PI\% >70).

Table-4. Percentage Inhibition (PI) of sera samples from FMD carrier trade cattle at Optical density (OD) of 450nm

\begin{tabular}{lcl}
\hline Percentage inhibition & Frequency & FMD carrier status \\
\hline$<50 \%$ & 112 & Negative \\
$50-70 \%$ & 69 & Weak \\
$70 \% \geq$ & 269 & Strong \\
Total & $338(75.11 \%)^{\star}$ & \\
\hline
\end{tabular}

* Prevalence of FMD carriers in cattle

\section{Discussion}

The FMD positive cattle in this market survey where either in the category of Percentage Inhibition (PI) PI of $\geq 50 \%-70 \%$ and or PI value of $\geq 70 \%$ that was considered as weak - strong positive respectively, 
this confirmed that such cattle had been recently exposed to FMD within the minimum of $\langle 40\rangle$ days as previously documented [16]. Thus considered as FMD carriers showing no clinical signs but have evidence of detectable antibodies giving an overall prevalence of $75.11 \%$ using ELISA kit (PRIOCHECK). This kit detects antibodies directed against the non-structural $3 \mathrm{ABC}$ protein of FMDV, confirming FMDV infected animals independent of animal vaccination status as vaccines consist of (partly) purified structural proteins of FMD virus and therefore vaccinated animals only elicits antibodies directed against the structural proteins of the virus, which is the basis of this discrimination between infected and vaccinated animals.

Overall prevalence of $75.11 \%$ in this survey is higher than National surveillance of FMD in which seroprevalence of $55.5 \%$ was reported [23], and also $64.30 \%$ documented [24] in nomadic herds from Plateau state as well as $56.3 \%$ in Jos south LGA in Plateau state [11]. The increased prevalence found in this study compared to previous studies may be associated with extensive movement of livestock, high rate of contact between animals at livestock markets, common grazing places as well as at watering point along cattle routes as earlier suggested [23] especially as this study area host the cattle internal market at Ilesha baruba, a Nigerian border town to Benin republic where these cattle are off loaded at Paraku and trek through cattle routes over a three day journey to the market for on ward distribution to other part of Nigeria. However, the $72.62 \%$ evidence of FMD non-structural protein antibodies reported for cattle in some states especially in the North West and North Eastern Nigeria [25] connotes this finding probably as those areas were Nigerian border towns and first portal of entry for trade cattle from East and Central Africa.

The distribution of sero-positive reactors by location in different Local Government Areas in the state (Fig.1) indicated that Ilesha baruba LGA recorded the highest occurrence of $22.48 \%$ (76/338). This was closely followed by Ilorin East LGA 20.71\% (70/338). Ilesha and Ilorin showed association with the occurrence of FMD. This could be attributed to influx of large number of cattle to meet up high demand for meat to satisfy the robust human population in the state capital (Ilorin) as well as heavy traffic and congregation of cattle from different sources at the Ilesha cattle market, especially those from West African trade route thus contaminating environment with FMDV. The variation of occurrence by location was similar to previous report [11].

Sex distribution indicated serpositivity was highest amongst female (cows) $62.13 \%$ (210/338) with highest occurrence in Ilesha $27.14 \%$ (57/210), Ilorin $23.80 \%$ (50/210) which showed association with FMDV antibody reactors. However, contrast previous study that stated no difference in risk association with FMD transmission between male and female animals
[26]. This variation maybe attributed to high number of female sampled at various locations as more cows are seemly found in markets following culling probably due to failing reproductive performance.

The distribution of sero-positive FMD carriers according to breeds in this study (Table II) showed that $77.21 \%$ white Fulani [Bunaji] was positive which indicated the highest occurrence over the other breeds of cattle such as Red bororo [Rahaji] and Sokoto Gudali [Bokoloji]. This finding could be associated with the predominance of white Fulani breed within cattle markets and ultimately their availability at time of sampling. Hence, this observation would require further elucidation to establish the possibility of any breed predisposition with FMD.

Seropositivity of FMD according to age (Table-3) showed that young cattle within 6 months- 2 years group had the highest occurrence $75.14 \%$ over the adult group. These young cattle were most poised for trade as their heavy availability in the markets could be associated with affordability and high turnover. This may also have fast tracked migration and contact with other FMD exposed cattle that suffered infection from multiple serotypes thus producing antibodies against all serotypes of FMD. This seroprevalence of FMD association with age was similar to previous report [11] that cattle within the age of $1-2 y$ rs are more prone to FMD.

The ELISA employed in this study showed that 112 sera was negative [PI\% <50\%], 69 sera as weak positive [PI\% $50-70 \%$ ] and 269 strong positive [PI\% >70] (Table-4). This High percentage occurrence of positive sera indicated poor vaccination control attempts amongst Nigerian local and trade cattle along the West Africa sub region as this technique screened off vaccinated cattle thus clarifying the doubtful vaccination status of the cattle during this survey. This population of cattle with unknown FMD vaccination history had made the disease endemic with mild course and mortality as earlier reported [11]. Previous studies demonstrated antibodies to SAT 1 and SAT 2 serotypes [7] however, serotyping of positive sera in this study is ongoing.

\section{Conclusion and recommendation}

This study provides preliminary information on the prevalence and endemicity as well as risk factors associated with FMD as FMD carriers was found in all sex, ages and breeds of unvaccinated trade cattle in kwara State of Nigeria as well as those imported by cattle trading partners along the West African coast. This confirms FMD as a transboundary cattle disease. Thus, circulating FMDV strains responsible for this seropositivity should be established in order to design appropriate control strategy to limit FMD effect.

It is therefore, recommended that continuous surveillance and quarantine of cattle within herds and inter-state and national borders should be encouraged. Eradication strategy through compulsory vaccinations 
using cost-effective vaccines made of circulating strains are also advocated.

\section{Authors' contributions}

OHO: This research work was part of doctorate investigation. HMK, MAR and NDI: designed, planned and organized the study as well as interpretation of result, discussion and review of manuscript. HMK and MAR also contributed in sample collection. All authors read and approved the final manuscript.

\section{Acknowledgements}

Authors are grateful to the Executive Director, National Veterinary Research Institute, Vom, Dr. Ahmed, M.S for granting us the permission to store and analyze the sera samples as well as Drs. Ularamu, H.G, Wungak Y.S and Mr. Agom, D for their assistance during the laboratory analysis. Personal fund of the author (OHO) was used for the execution of this survey.

\section{Competing interests}

The authors declare that they have no competing interests.

\section{References}

1. Domingo, E., Baranowski, E., Escarmís, C., and Sobrino, F. (2002) Foot-and-mouth disease virus. Comp. Immunol. Microbiol. Infect. Dis. 25: 297-308.

2. Shao, J., Hui-Yun, C., Guang-Qing, Z., Guo-Zheng, C., JunZheng, D., Tong, L., Shan-Dian, G., Ji-Jun, H., Xiang-Tao, L., Ji-Xing, L., and Jin-Liang, G. (2010) RT Rapid Detection of Foot-and-Mouth Disease Virus by Reverse Transcription Loop-mediated Isothermal Amplification (RT-LAMP) $J$ Appl Res Vet Med. 8(2):133-140.

3. Rweyemamu, M., Roeder, P., Mackay, D., Sumption, K., Brownlie, J., Leforban, Y., Valarcher, J.F., Knowles, N.J., and Saraiva, V. (2008) Epidemiological Patterns of Foot-andMouth Disease Worldwide. J. Transboundary Emerg. Dis. 55: 57-72.

4. Nawathe, D.R. and Goni, M. (1976) Foot-and-Mouth Disease in Nigeria. Bull. Anim. Health Prod. Afr. 24: (1) 1-4.

5. Durojaiye, A.O. (1981) Incidence of foot and mouth disease in Oyo State of Nigeria. Niger. Vet. J. 10: 7-13.

6. Abegunde, A.A. (1987) Studies on the epidemiology of foot and mouth disease in Nigeria. PhD Thesis. Ahmadu Bello University, Zaria: 124-126 Pp.

7. Chukwuedo A. A., Nimzing L., Olabode, A.O. and Abegunde, A. (2008) Prevalence of Foot and Mouth disease Virus, SAT 1 and SAT 2 serotype antibodies in Nigerian cattle. Anim. Prod. Res. Adv. 4(2): 157-160.

8. Nwanta, J.A. and Ojemiren, F.O. (2000) Epidemiology of Foot and Mouth Disease (FMD) in northern states of Nigeria. Up-date In: Proceedings of the $36^{\text {th }}$ Annual Congress of the National Veterinary Medical Association held in Kaduna, $25^{\text {th }}-29^{\text {th }}$ October 2000. Pp 11-18.

9. Olabode, H.O.K., Kazeem, H. M., Raji, M.A., and Ibrahim, N.D.G (2012) Foot and Mouth disease in Nigeria: The current status and control efforts. A Paper presented at the Global Foot and Mouth Disease Research Alliance workshop organized by ARC-Onderstepoort Veterinary Institute, held at Hazy-view, Kurger National Park, South Africa on the $17^{\text {th }}-19^{\text {th }}$ April, 2012.

10. Chukwuedo A. A., Abegunde A., and Gomwalk N.E. (2003) Studies on current status of foot and mouth disease virus in Nigeria. Niger J Biotech. 14 (1):22-28.

11. Ishola, O. O., Wungak, Y. S., Olugasa B. O., David L. D., and Ekong, P.S. (2011) Serological survey of Foot and Mouth disease in cattle in Jos south local government area of Plateau state. Vom J. Vet. Sci. 8: 16-21.

12. Hamblin, C., Barnett, I. T. R. and Hedger, R.S. (1986) A new enzyme linked immunosorbent assay (ELISA) for the detection of antibodies against foot-and-mouth disease virus, I. Development and method of ELISA, J. Immunol. Meth. 93: 115-121.

13. Bergmann I. E., de Mello P.A., Neitzert E., Beck E. and Gomes I. (1993) Diagnosis of persistent aphthovirus infection and its differentiation from vaccination response in cattle by use of enzyme-linked immunoelectrotransfer blot analysis with bioengineered nonstructural viral antigens. Am. J. Vet. Res. 54: 825-831.

14. De Diego, M., Brocchi, E., Mackay, D. and De Simone, F. (1997) The nonstructural polyprotein 3ABC of foot-andmouth disease virus as a diagnostic antigen in ELISA to differentiate infected from vaccinated cattle. Arch. Virol. 142:2021-2033.

15. Mackay, D. K., Forsyth, M.A., Davies, P.R., Berlinzani, A., Belsham, G.J., Flint, M. and Ryan, M.D. (1998) Differentiating infection from vaccination in foot-andmouth disease using a panel of recombinant, non-structural proteins in ELISA. Vaccine. 16: 446-459.

16. Sorensen, K. J., Madsen, K.G., Madsen, E.S., Salt, J.S., Nqindi, J. and Mackay, D.K. (1998) Differentiation of infection from vaccination in foot-and-mouth disease by the detection of antibodies to the non-structural proteins 3D, $3 \mathrm{AB}$ and $3 \mathrm{ABC}$ in ELISA using antigens expressed in baculovirus. Arch. Virol. 143: 1461-1476.

17. Clavijo A., Wright, P. and Kitching, P. (2004)Developments in diagnostic techniques for differentiating infection from vaccination in Foot and Mouth disease. Vet. J. 167: 9-22.

18. Ferris, N.P. and Dawson, M. (1988) Routine application of enzyme-linked immunosorbent assay in comparison with complement fixation for the diagnosis of foot-and-mouth and swine vesicular disease. Vet. Microbiol 16: 201-209.

19. Office International for Epizootics [OIE] (2008) Foot and mouth disease In: OIE Terrestrial Manual Chapter 2.1.5, 190-215.

20. Anonymous (2010) Geographic information of Kwara state http://www.geonames. org/ 2332785/kwara.html: Accessed on 12 June 2010.

21. Anonymous (2011) Kwara State www. kwarastate.gov.ng http://en.wikipedia.org/wiki/kwara state Accessed on 20 July 2011.

22. Rufael, T., Catley, A., Bogale, A., Sahle, M., and Shiferaw, Y. (2008) Foot and mouth disease in the Borana pastoral system, southern Ethiopia and implications for livelihoods and international trade Trop. Anim. Health. Prod. 40:29-38.

23. Abegunde A.A., Ezeokoli C.D., Umoh J.U., and Addo P.B. (1988) Epidemiology of Foot and mouth disease in Nigerian cattle. Viral Diseases of animals in Africa. OAU/STRC Scientific Publication Lagos Nigeria, pp 203-212.

24. Ehizibolo, D.O., Ajogi, I., Umoh, J.U., Kazeem, H.M., Ehizibolo, P.O, Perez, A.M. and Metwally, S.A. (2010) Serological survey of Foot and Mouth Disease (FMD) 3d Non-structural Proteins using virus-infection associated (VIA) Antigen assay in livestock animals from Plateau State, Nigeria In: Book of Abstract 47th Annual Congress of the Nigerian Veterinary Medical Association, Benue 2010. Pp.75.

25. Lazarus, D. D., Schielen, W. J. G., Wungak, Y., Kwange, D., and Fasina, F. O. (2012) Sero-epidemiology of foot-andmouth disease in some Border States of Nigeria. Afr. $J$. Microbiol.Res. 6(8): 1756-1761.

26. Jenbere, T.S., Etana, M., and Negussie, H. (2011) Study on the risk factors of Foot-and-Mouth disease in selected Districts of Afar Pastoralist Area, North-Eastern Ethiopia. $J$. Anim. Vet. Adv. 10: 1368-1372.

$* * * * * * * *$ 